\title{
Effect of $\mathrm{AIN}$ and $\mathrm{Al}_{2} \mathrm{O}_{3}$ additions on the phase relationships and morphology of $\mathrm{SiC}$
}

\author{
Part I Compositions and properties
}

\author{
GREG E. HILMAS \\ Department of Ceramic Engineering, University of Missouri-Rolla, Rolla, MO 65409-0330 \\ E-mail: ghilmas@umr.edu
}

TSENG-YING TIEN

Department of Materials Science and Engineering, The University of Michigan, Ann Arbor, MI 48109-2136

\begin{abstract}
X-ray diffraction was utilized to follow the transformation from $\beta$-SiC (3C) to the various $\alpha$-SiC polytypes in the presence of AIN and $\mathrm{Al}_{2} \mathrm{O}_{3}$ additives after hot pressing from 1700 to $2100{ }^{\circ} \mathrm{C}$. The $2 \mathrm{H}$ - and $6 \mathrm{H}$-polytypes of $\alpha$-SiC were the predominate polytypes with additions of only AIN or $\mathrm{Al}_{2} \mathrm{O}_{3}$, respectively. The amount of $2 \mathrm{H}$ - and $6 \mathrm{H}$-polytypes, and subsequently the microstructural morphology of the $\mathrm{SiC}$ materials, were found to be controlled by varying the amount of $\mathrm{AIN}$ and $\mathrm{Al}_{2} \mathrm{O}_{3}$. Improvements in fracture toughness to $\sim 9 \mathrm{MPa}-\sqrt{\mathrm{m}}$ were achieved with flexural strengths ranging from 600 to $900 \mathrm{MPa}$. These results suggest that accurate control of the polytypic make-up of SiC-based materials, along with their mechanical properties, can be achieved through AIN and $\mathrm{Al}_{2} \mathrm{O}_{3}$ additions. (c) 1999 Kluwer Academic Publishers
\end{abstract}

\section{Introduction}

The transformation of $\beta$-SiC (3C) at high temperature to one or more of the $\alpha-\mathrm{SiC}$ polytypes $(2 \mathrm{H}, 4 \mathrm{H}$, $15 \mathrm{R}, 6 \mathrm{H}$, etc.) has been investigated extensively with results showing the transformation and the resulting $\alpha$-polytype formed to be strongly dependent on the polytypic make-up of the starting $\mathrm{SiC}$ powder, the sintering temperature, and the amount and type of additives used $[1,2]$. Small additions of $\mathrm{Al}, \mathrm{B}$, and $\mathrm{C}$ or $\mathrm{BeO}$ to $\beta$-SiC (3C) have predominantly resulted in transformation to the 4H-polytype of $\alpha$-SiC [3]. While small additions of only $\mathrm{B}$ and $\mathrm{C}$ to $\beta$-SiC have produced transformations to the $6 \mathrm{H}$-polytype [4]. Strongly affected by the present research is the finding by several authors that $\beta-\mathrm{SiC}(3 \mathrm{C})$ preferentially transforms to $\alpha-\mathrm{SiC}(2 \mathrm{H})$ in the presence of $\operatorname{AlN}(2 \mathrm{H})$. This can occur over a broad range of SiC-AlN mixtures, typically from 35 to $100 \mathrm{wt} \% \mathrm{AlN}$, and is accompanied by an extensive $2 \mathrm{H}$ solid-solution above $2050{ }^{\circ} \mathrm{C}[5,6]$.

The intent of this study was to control the overall phase content, microstructural morphology and mechanical properties of a series of SiC-based composites utilizing both $\mathrm{AlN}$ and $\mathrm{Al}_{2} \mathrm{O}_{3}$ as additives. This paper will deal mainly with the processing, fabrication, post-fabrication phase analysis, and mechanical properties of the compositions. Emphasis is on observing the transformation from $\beta-\mathrm{SiC}$ to one or more of the $\alpha-\mathrm{SiC}$ polytypes and determination of the phase content in terms of percent $\mathrm{SiC}$-polytypes. Mechanical properties results include measurements of the room temperature fracture toughness, and flexural strengths at both room temperature and elevated temperatures.

The second paper will describe in detail the morphology of the microstructures formed in this series of compositions and will show that the major SiC-polytype formed and its resultant morphology are strongly affected by the quantity of $\mathrm{AlN}$ and $\mathrm{Al}_{2} \mathrm{O}_{3}$ added to the starting $\mathrm{SiC}$ powder.

\section{Experimental procedure}

\subsection{Compositions and powder processing}

The ceramic raw materials used in this study were $\mathrm{SiC}$, $\mathrm{AlN}$ and $\mathrm{Al}_{2} \mathrm{O}_{3}$. The starting $\mathrm{SiC}$ powder was $\beta$-SiC (Grade B10, $>95 \% \beta$-SiC (3C), Hermann C. Starck, Goslar, FRG) with a mean particle size of $0.6 \mu \mathrm{m}$. The major impurities in the $\mathrm{SiC}$ powder are $0.92 \% \mathrm{O}$, $0.024 \% \mathrm{Fe}$ and $0.011 \% \mathrm{Al}$. The AlN powder (Keramont Corp., Tucson, AZ) had an average particle size $\leq 1.0 \mu \mathrm{m}$ and the major impurities were $1.2 \% \mathrm{O}$ and $0.2 \%$ C. The $\mathrm{Al}_{2} \mathrm{O}_{3}$ (Grade A-16, Alcoa Industrial Chemicals, Bauxite, AR) had an average particle size $0.7 \mu \mathrm{m}$ and the major impurities were $0.006 \% \mathrm{Fe}$.

The compositions formed are outlined in Table I and are referred to by their respective starting powders in terms of volume percent of $\beta$-SiC powder with a $3: 1$ molar ratio of AlN: $\mathrm{Al}_{2} \mathrm{O}_{3}$ making up the remainder of each composition: i.e. $90 \mathrm{vol} \% \beta$-SiC $+10 \mathrm{vol} \%$ $3 \mathrm{AlN}: 1 \mathrm{Al}_{2} \mathrm{O}_{3}=\mathrm{BS} 90$. Each composition also contained $0.5 \mathrm{wt} \% \mathrm{~B}$ added as a sintering aid. The $3: 1$ 
TABLE I Compositions of $\beta$-SiC: $\mathrm{AlN}: \mathrm{Al}_{2} \mathrm{O}_{3}$ series and standards

\begin{tabular}{|c|c|c|c|c|c|}
\hline \multirow[b]{2}{*}{ Sample } & \multicolumn{2}{|r|}{ Vol \% } & \multicolumn{3}{|c|}{ wt $\%$} \\
\hline & $\beta-\mathrm{SiC}$ & $3 \mathrm{AlN}: 1 \mathrm{Al}_{2} \mathrm{O}_{3}$ & $\mathrm{SiC}$ & AlN & $\mathrm{Al}_{2} \mathrm{O}_{3}$ \\
\hline BS50 & 50 & 50 & 47.55 & 28.67 & 23.78 \\
\hline BS60 & 60 & 40 & 57.62 & 23.17 & 19.21 \\
\hline BS70 & 70 & 30 & 67.91 & 17.54 & 14.55 \\
\hline BS80 & 80 & 20 & 78.39 & 11.81 & 9.80 \\
\hline BS90 & 90 & 10 & 89.08 & 5.97 & 4.95 \\
\hline BS100 & 100 & - & 100 & - & - \\
\hline BS90: 10N & 90 & $10 \mathrm{AlN}$ & 89.88 & 10.12 & - \\
\hline BS90 : 100 & 90 & $10 \mathrm{Al}_{2} \mathrm{O}_{3}$ & 87.94 & - & 12.06 \\
\hline
\end{tabular}

molar ratio for the $\mathrm{AlN}: \mathrm{Al}_{2} \mathrm{O}_{3}$ additions was chosen through extensive research by the authors in an attempt to form several AlN-polytypoids [7] $\left(\mathrm{Al}_{5} \mathrm{O}_{2} \mathrm{~N}_{3}\right.$ for the $3: 1$ composition) in situ within a SiC matrix [8]. Early results showed that $\mathrm{SiC}$ compositions hot-pressed above $2050^{\circ} \mathrm{C}$, and containing 20 weight percent of the 3:1 AlN : $\mathrm{Al}_{2} \mathrm{O}_{3}$ molar additions, achieved near theoretical density with a fracture toughness nearly twice that of phase pure $\mathrm{SiC}$ processed under the same conditions. The current paper is an expansion of these results whereby the additions of $3 \mathrm{AlN}: 1 \mathrm{Al}_{2} \mathrm{O}_{3}$ are being varied with respect to the $\mathrm{SiC}$ matrix material.

The compositions were prepared by attrition milling raw powders as $50 \mathrm{~g}$ charges in a teflon lined milling jar using $2 \mathrm{~mm}$ diameter alumino-silicate milling media and isopropyl alcohol. The milling time was $3 \mathrm{~h}$ for each composition. The milled slurry was then oven dried overnight at $85^{\circ} \mathrm{C}$ to obtain the powder.

\subsection{Specimen fabrication}

In preparation for hot-pressing, the milled and dried powder was placed in a graphite die that was lightly coated with boron nitride powder to suppress bonding of the $\mathrm{SiC}$ to the die during hot-pressing. The powder was cold-pressed uniaxially in the die under a $25 \mathrm{MPa}$ load and then placed in a graphite resistance furnace, and heated under vacuum to $1000^{\circ} \mathrm{C}$ at a rate of approximately $40^{\circ} \mathrm{C} / \mathrm{min}$. At $1000^{\circ} \mathrm{C}$ the furnace was flushed and filled with nitrogen gas, and the heating rate was increased to approximately $60 \% \mathrm{~min}$. A 'flowing' nitrogen atmosphere of slightly greater than $1 \mathrm{~atm}$ was constantly maintained in attempt to limit decomposition of the phases at high temperature. A $25 \mathrm{MPa}$ load was applied during the heating cycle above $1000^{\circ} \mathrm{C}$ and released upon cooling below $1000^{\circ} \mathrm{C}$. The compositions (BS90, BS80, BS70, BS60 and BS50) were prepared by hot-pressing at $1700,1800,1900$, and $2000^{\circ} \mathrm{C}$ for $1 \mathrm{~h}$ hold times and at $2100^{\circ} \mathrm{C}$ for times of 1,2 and $5 \mathrm{~h}$. All specimens hot-pressed at $1800^{\circ} \mathrm{C}$ and above were $>98 \%$ dense as measured by water displacement.

In order to determine the effect of the AlN and $\mathrm{Al}_{2} \mathrm{O}_{3}$ additives on the polytypic phase content of the $\mathrm{SiC}$ matrix, three standards were also prepared by hot pressing at $2100{ }^{\circ} \mathrm{C}$ for $1 \mathrm{~h}$ using the processing method described above. These standards included $100 \% \beta$-SiC (BS100), 90 vol \% $\beta$-SiC with 10 vol \%
AlN (BS90: $10 \mathrm{~N}$ ), and 90 vol $\% \beta$-SiC with $10 \mathrm{vol} \%$ $\mathrm{Al}_{2} \mathrm{O}_{3}$ (BS90 : 10O).

\subsection{X-ray diffraction analysis}

Often overlooked in the study of $\mathrm{SiC}$ is the difficulty in readily determining the overall SiC-polytype phase content from bulk analytical methods like X-ray diffraction. The multitude of possible transformations, the presence of many of the polytypes during high temperature forming, and ultimately the overlap of their diffraction peaks makes quantification difficult. The accepted method to accomplish this goal has been to utilize the experimentally calculated and measured single-crystal data, and thus quantified X-ray intensity equations of Ruska et al. [9]. Unfortunately, their results do not allow for the presence of the 2H-polytype of $\alpha$-SiC which is present in our material. However, the calculations are relatively straightforward, permitting the $2 \mathrm{H}$-polytype to be added to their results [8]. In brief, the atomic positions for the $2 \mathrm{H}$-polytype (space group- $\mathrm{P}_{3} \mathrm{mc}$ ) were obtained from Wyckoff [10]. In line with the calculations of Ruska et al. [9], atomic scattering factors were calculated using $\mathrm{Si}^{2+}$ and $\mathrm{C}^{2-}$ calculated by linear extrapolation from tabulated data [11] for $\mathrm{Si}^{0}, \mathrm{Si}^{3+}$ and $\mathrm{C}^{0}, \mathrm{C}^{2+}$. The $\mathrm{X}$-ray intensities were then calculated from the following equation:

$$
I_{\mathrm{n}}=m[F]^{2} \times \mathrm{LP} / V^{2}
$$

where $I_{\mathrm{n}}$ is the intensity normalized to the unit cell volume- $V, m$ is the multiplicity, $F$ is the structure factor, and LP is the Lorentz-polarization factor. Table II shows the factors and resultant X-ray intensities for the 2H-polytype for the reflections in the range of 0.266 to $0.217 \mathrm{~nm}$. These intensities were then normalized to the strongest diffraction line or $I_{100}$ for pure $3 \mathrm{C}-\mathrm{SiC}$. Table III outlines the final equations for quantifying the amount of SiC-polytypes utilizing the new calculated data for $2 \mathrm{H}-\mathrm{SiC}$ and the calculated and measured data for $15 \mathrm{R}, 6 \mathrm{H}, 4 \mathrm{H}$ and $3 \mathrm{C}$ [9].

In order to gain insight into the formation of the different $\mathrm{SiC}$ polytypes it was necessary to follow the solid-state transformation among the polytypes during the hot-pressing cycle. Therefore, samples were taken at each temperature and composition from the hot-pressed billets. The samples were then machined into $3 \times 3 \times 10 \mathrm{~mm}$ bars, cleaned, and crushed into a fine powder using a vibratory tungsten carbide ball and mortar. The powder samples were evaluated by Xray diffraction (XRD) performed on a rotating anode diffractometer* utilizing monochromated $\mathrm{Cu} K_{\alpha}$ radiation. A $60 \mathrm{rpm}$ motor was added to the X-ray stage to rotate the samples. Along with using a fine powder, the rotation of the sample helps to eliminate any disparity between calculated and observed X-ray intensities due to both extinction and preferred orientation. The range scanned was $32^{\circ}$ to $45^{\circ} 2 \theta$, and the low rpm motor required scan rates to be slowed to $1 \% \mathrm{~min}$.

\footnotetext{
* Rigaku/USA, Inc., Model No. RU-200BH, Danvers, MA.
} 
TABLE II Calculated X-ray intensities for the 2H-polytype of $\alpha$-SiC

\begin{tabular}{rrrrrr}
\hline$h k l$ & $d(\mathrm{~nm})$ & $F$ & $(F / V)$ & $m$ & LP \\
\hline 100 & 0.2669 & 14.21 & 0.3436 & 6 & 21.20 \\
002 & 0.2515 & 20.88 & 0.5049 & 6 & 15.016 \\
101 & 0.2357 & 12.38 & 0.2993 & 12 & 16.461 \\
\hline
\end{tabular}

TABLE III Equations for calculating SiC-polytypes from XRD peak intensities

\begin{tabular}{|c|c|c|c|c|c|c|c|c|c|c|c|}
\hline $15 R^{a}$ & & $6 \mathrm{H}^{\mathrm{a}}$ & & $4 \mathrm{H}^{\mathrm{a}}$ & & $2 \mathrm{H}$ & & $3 C^{a}$ & & Peak & $d(\mathrm{~nm})$ \\
\hline $3.2 \mathrm{a}$ & & & + & $9.9 \mathrm{c}$ & + & $39.4 \mathrm{~d}$ & & & $=$ & A & 0.266 \\
\hline $11.2 \mathrm{a}$ & + & $19.4 b$ & & & & & & & $=$ & B & 0.263 \\
\hline $26.0 \mathrm{a}$ & & & + & $38.9 \mathrm{c}$ & & & & & $=$ & $\mathrm{C}$ & 0.257 \\
\hline \multirow[t]{2}{*}{$31.1 \mathrm{a}$} & + & $59.2 b$ & + & $25.1 \mathrm{c}$ & + & $24.8 \mathrm{~d}$ & + & $100.0 \mathrm{e}$ & $=$ & $\mathrm{D}$ & 0.251 \\
\hline & & $18.1 \mathrm{~b}$ & + & $34.1 \mathrm{c}$ & + & $45.1 \mathrm{~d}$ & & & $=$ & $\mathrm{E}$ & 0.235 \\
\hline $2.4 \mathrm{a}$ & + & $6.5 b$ & & & & & + & $13.1 \mathrm{e}$ & $=$ & $\mathrm{F}$ & 0.217 \\
\hline
\end{tabular}

${ }^{\mathrm{a}}$ Calculated and measured data taken from reference [7].

\subsection{Mechanical property measurements}

Sections of the hot-pressed samples were diamond machined and then ground and polished to a $0.1 \mu \mathrm{m} \mathrm{di-}$ amond finish in order to measure microhardness and fracture toughness. A standard Vicker's diamond indenter was placed in a microhardness testing machine* for all measurements. Indentation loads varied from 5 to $25 \mathrm{~kg}$ depending upon the sample and to fulfill the requirement that the radial/median cracks be equal to or greater than twice the Vicker's indentation diagonal. The fracture toughness, $K_{\text {Ic }}$, was then calculated from an average of ten indents using the equation of Anstis et al. [12].

Flexural strengths and additional fracture toughness measurements were made using four-point bend test techniques $[13,14]$. The test bars for four-point bending were diamond machined from each hot-pressed billet to a final size of $20 \times 3 \times 2.25 \mathrm{~mm}$. In order to alleviate any strength or toughness anisotropy, all test specimens were machined such that the tensile face was perpendicular to the hot-pressing direction. The tensile surfaces were polished to a $1 \mu \mathrm{m}$ diamond finish, and the edges of the bars were chamfered. All tests were performed using a specially designed self-aligning fourpoint bend test fixture made from hot-pressed $\mathrm{SiC}$. The fixture also contained cylindrical $\mathrm{SiC}$ supports and had an outer span of $16 \mathrm{~mm}$ and inner span of $8 \mathrm{~mm}$. A universal Instron testing machine was utilized to fracture the test bars using computer control. The room temperature was $\sim 27^{\circ} \mathrm{C}$, and the crosshead speed, $s$, was $5 \times 10^{-3} \mathrm{in} / \mathrm{min}$. This crosshead speed corresponded to a strain rate, $\dot{\varepsilon}$, of $1 \times 10^{-4} / \mathrm{s}$. Measurements of the flexural strength, $\sigma$, were obtained from three bars at each of four different temperatures (room temperature $-27^{\circ} \mathrm{C}, 900^{\circ} \mathrm{C}, 1200^{\circ} \mathrm{C}$ and $1400^{\circ} \mathrm{C}$ ).

Fracture toughness in four-point bending was measured by the controlled surface flaw method on BS90 samples to corroborate the data obtained by the indentation technique. A Vicker's diamond indentation was made at the center of the test bars on the tensile surface while making sure to keep the indent oriented or-

* Zwick of America, Inc., Model No. 3212, East Windsor, CT.

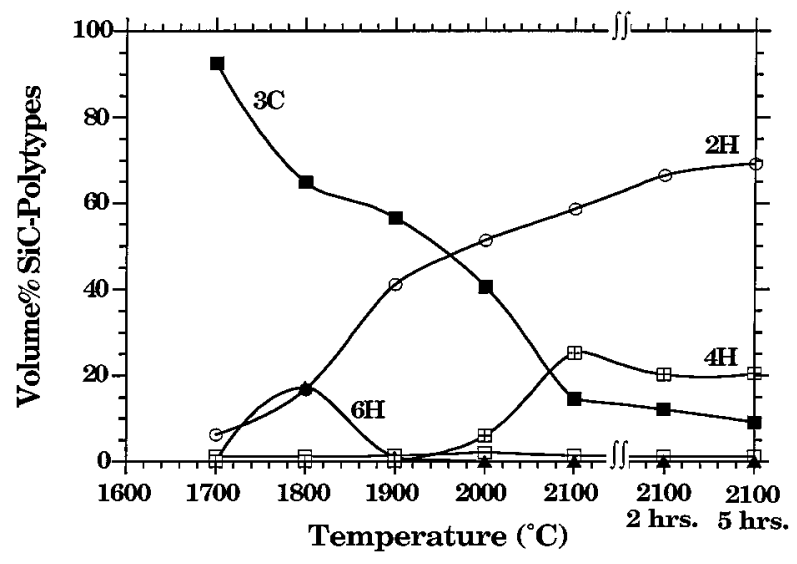

Figure 1 Plot of vol\% SiC polytype vs. hot-pressing temperature for composition BS50 hot pressed for $1 \mathrm{~h}$ hold times up to $2100^{\circ} \mathrm{C}$, and $2100^{\circ} \mathrm{C}$ for 2 and $5 \mathrm{~h}$.

thogonally to the longitudinal axis of the test bar. An indentation load of $15 \mathrm{~kg}$ was used for all test bars, and following fracture, $K_{\text {Ic }}$ was calculated using the equation of Chantikul et al. [15].

\section{Results and discussion}

\subsection{X-ray diffraction analysis}

The data for the BS series samples is shown graphically in Figs 1-5. For each composition, a plot of vol \% SiC-polytype versus hot-pressing temperature from 1700 to $2100{ }^{\circ} \mathrm{C}$ for hot pressing hold times of $1 \mathrm{~h}$ are represented along with data at $2100^{\circ} \mathrm{C}$ for hold times of 2 and $5 \mathrm{~h}$. The data clearly shows that the transformation to the high temperature SiC-polytype is compositionally dependent.

Compositions BS50 and BS60 both transform rapidly to the $2 \mathrm{H}$-polytype of $\mathrm{SiC}$, as shown in Figs 1 and 2, respectively. These compositions exhibit an intermediate development of a $6 \mathrm{H}$-polytype with a maximum occurring at $2000{ }^{\circ} \mathrm{C}$ for BS60 and $1800{ }^{\circ} \mathrm{C}$ for BS50. The 6H-polytype is subsequently consumed at higher temperatures to form more of the $2 \mathrm{H}$-polytype. Appreciable amounts of the $4 \mathrm{H}$-polytype are starting to form along with $2 \mathrm{H}$ above $2000{ }^{\circ} \mathrm{C}$, only to be 


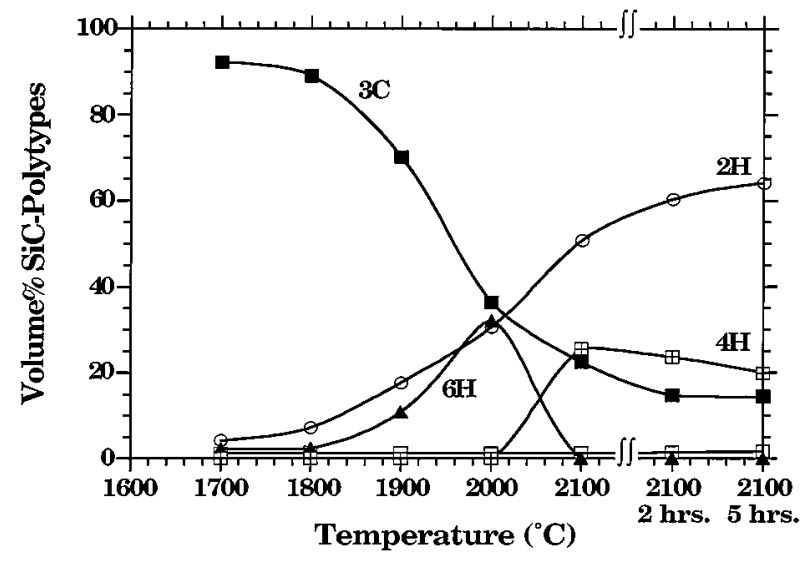

Figure 2 Plot of vol\% SiC polytype vs. hot-pressing temperature for composition BS60 hot pressed for $1 \mathrm{~h}$ hold times up to $2100^{\circ} \mathrm{C}$, and $2100{ }^{\circ} \mathrm{C}$ for 2 and $5 \mathrm{~h}$.

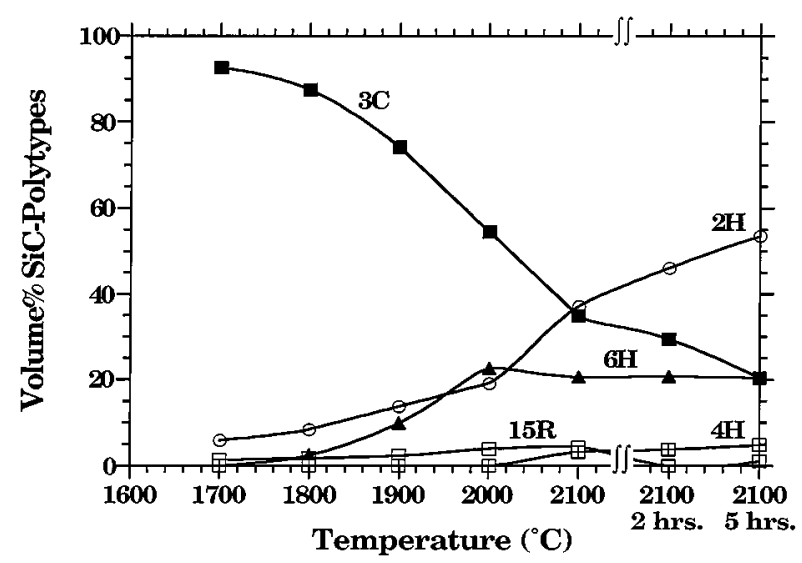

Figure 3 Plot of vol\% SiC polytype vs. hot-pressing temperature for composition BS70 hot pressed for $1 \mathrm{~h}$ hold times up to $2100^{\circ} \mathrm{C}$, and $2100^{\circ} \mathrm{C}$ for 2 and $5 \mathrm{~h}$

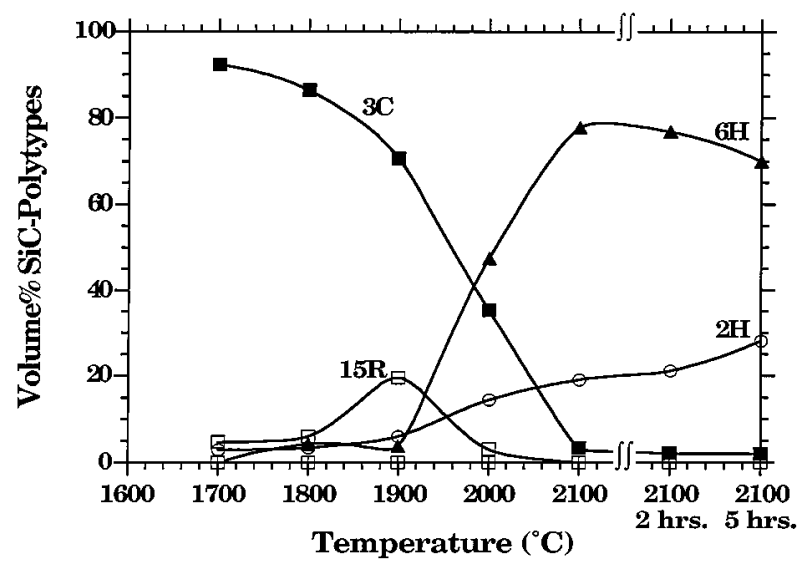

Figure 4 Plot of vol \% SiC polytype vs. hot-pressing temperature for composition BS80 hot pressed for $1 \mathrm{~h}$ hold times up to $2100{ }^{\circ} \mathrm{C}$, and $2100^{\circ} \mathrm{C}$ for 2 and $5 \mathrm{~h}$.

slowly consumed along with more $3 \mathrm{C}-\mathrm{SiC}$ to form the $2 \mathrm{H}$-polytype. After $5 \mathrm{~h}$ at $2100^{\circ} \mathrm{C}$, BS50 and BS60 contain approximately 70 and 65 vol \% of $2 \mathrm{H}-\mathrm{SiC}$, respectively, $20 \mathrm{vol} \%$ of the $4 \mathrm{H}$-polytype, and the remainder being untransformed $\beta$-SiC.

The BS70 composition, Fig. 3, shows a strong competition between forming the $2 \mathrm{H}$ - and $6 \mathrm{H}$-polytypes. These polytypes start to form slowly above $1800{ }^{\circ} \mathrm{C}$ with the 6H-polytype reaching a peak of $\sim 20 \mathrm{vol} \%$

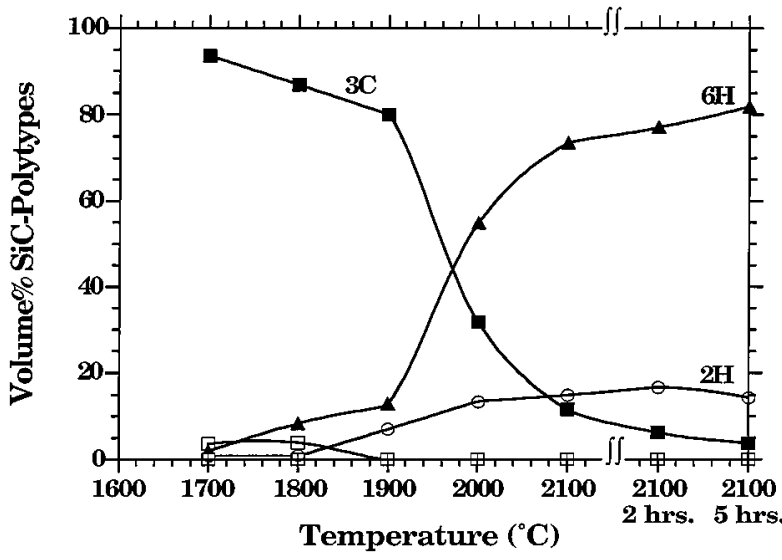

Figure 5 Plot of vol \% SiC polytype vs. hot-pressing temperature for composition BS90 hot pressed for $1 \mathrm{~h}$ hold times up to $2100^{\circ} \mathrm{C}$, and $2100^{\circ} \mathrm{C}$ for 2 and $5 \mathrm{~h}$.

at $2000^{\circ} \mathrm{C}$. Only minor quantities of the $4 \mathrm{H}$ - and $15 \mathrm{R}-$ polytypes form as intermediate phases, never achieving more than 5 vol \% of either polytype. While the sample still retains some $3 \mathrm{C}-\mathrm{SiC}$ after $5 \mathrm{~h}$ at $2100^{\circ} \mathrm{C}$, only the $2 \mathrm{H}$-polytype is increasing quantity vs. all other polytypes for times longer than $1 \mathrm{~h}$ at $2100{ }^{\circ} \mathrm{C}$.

In Fig. 4, the BS80 composition has transformed predominantly to the $6 \mathrm{H}$-polytype, but with an intermediate development of the 15R-polytype which achieved a maximum of $\sim 20 \mathrm{vol} \%$ at $1900{ }^{\circ} \mathrm{C}$. The $15 \mathrm{R}$-polytype was subsequently consumed above $1900^{\circ} \mathrm{C}$ in favor of the $6 \mathrm{H}$-polytype and some formation of the $2 \mathrm{H}$ polytype. The quantity of $6 \mathrm{H}$-polytype actually decreased slightly for longer times at $2100{ }^{\circ} \mathrm{C}$. After $5 \mathrm{~h}$ at $2100{ }^{\circ} \mathrm{C}$ the sample contains $70 \mathrm{vol} \%$ of $6 \mathrm{H}-\mathrm{SiC}$ and $\leq 30 \mathrm{vol} \%$ of $2 \mathrm{H}-\mathrm{SiC}$.

Fig. 5 shows composition BS90 transforming almost exclusively to the $6 \mathrm{H}$-polytype in the range of 1900 $2100{ }^{\circ} \mathrm{C}$ with only slight amounts of the $2 \mathrm{H}$-polytype. The $2 \mathrm{H}$-polytype forms progressively above $1800^{\circ} \mathrm{C}$, leveling off to $\sim 15 \mathrm{vol} \%$ after $5 \mathrm{~h}$ at $2100{ }^{\circ} \mathrm{C}$. The final composition contains $>80$ vol $\%$ of $6 \mathrm{H}-\mathrm{SiC}$ with $\sim 5$ vol $\%$ of untransformed $\beta$-SiC.

The results of this investigation emphasize the composition and additive dependence to the polytypism in the transformed $\alpha$-SiC matrix. For compositions BS90 and $\mathrm{BS} 80$, having $10-20$ vol \% $3 \mathrm{AlN}: 1 \mathrm{Al}_{2} \mathrm{O}_{3}$, respectively, the preferred SiC-polytype is $6 \mathrm{H}$. Larger additions of $30-50$ vol \% $3 \mathrm{AlN}: 1 \mathrm{Al}_{2} \mathrm{O}_{3}$ resulted in a competition between the development of the $6 \mathrm{H}$ - and the $2 \mathrm{H}$-polytype, with the $2 \mathrm{H}$-polytype predominating at higher temperatures, longer times, and an increasing percentage of $\mathrm{AlN}$ and $\mathrm{Al}_{2} \mathrm{O}_{3}$ additives. Based on the $\mathrm{XRD}$ results after $5 \mathrm{~h}$ at $2100^{\circ} \mathrm{C}$, it is apparent that regions of stability exist for the $\alpha$-SiC polytypes formed under the conditions of this study. The current results are not an attempt to determine the actual 'equilibrium' phase diagram for the $\mathrm{SiC}-\mathrm{AlN}-\mathrm{Al}_{2} \mathrm{O}_{3}$ system, but the data does provide a guideline that can be used to exert control over the phase content and microstructural morphology of SiC-based ceramic materials utilizing simultaneous additions of $\mathrm{AlN}$ and $\mathrm{Al}_{2} \mathrm{O}_{3}$.

The XRD data for the standards BS100, BS90:10N, and BS90:10O is shown in Table IV, including the 
major and minor polytypes of $\mathrm{SiC}$ that have formed after $1 \mathrm{~h}$ at $2100{ }^{\circ} \mathrm{C}$. As expected from previous research $[5,6]$, the addition of AlN resulted in a transformation to the $2 \mathrm{H}$-polytype of $\alpha$-SiC. Alternately, additions of $\mathrm{Al}_{2} \mathrm{O}_{3}$ resulted in a transformation to predominantly the $6 \mathrm{H}$-polytype of $\alpha$-SiC. The BS100 composition transformed to a mixture of the $6 \mathrm{H}$ - and $4 \mathrm{H}$-polytypes of $\alpha$-SiC along with minor quantities of the $15 \mathrm{R}$ - and 3C-polytypes.

\subsection{Mechanical property measurements}

The results of elastic modulus, Poisson's ratio, hardness, and fracture toughness measurements for samples hot pressed at $2100{ }^{\circ} \mathrm{C}$ for $1 \mathrm{~h}$ are summarized in Table $\mathrm{V}$. The most prominent results from this data are the fracture toughness and hardness values. The $\beta$-SiC standard is typical of hot-pressed SiC materials, having an indentation fracture toughness in the range of 2.5-3.0 MPa- $\sqrt{\mathrm{m}}$. Samples BS50, BS60 and BS70 had similar fracture toughness values ranging from 2.7 to $2.9 \mathrm{MPa}-\sqrt{\mathrm{m}}$. Sample BS80 showed a definite increase in fracture toughness to $5.3 \mathrm{MPa}-\sqrt{\mathrm{m}}$, while the BS90 composition exhibited the greatest increase in fracture toughness, achieving $8.5 \mathrm{MPa}-\sqrt{\mathrm{m}}$. Concurrent with the increase in fracture toughness for the latter two compositions is a precipitous decrease in hardness dropping to $18.6 \mathrm{GPa}$ for the $\mathrm{BS} 80$ composition to a low of 14.8 GPa for BS90. This combination of properties would most likely be attributed to the formation of microcracks. Although microcracks were not observed in the present work, liquid phase sintered SiC materials have been shown to exhibit microcrack toughening behavior
TABLE IV X-ray diffraction results for SiC standards

\begin{tabular}{lll}
\hline $\begin{array}{l}\text { Sample } \\
\text { code }\end{array}$ & $\begin{array}{l}\text { Major SiC- } \\
\text { polytypes }\end{array}$ & $\begin{array}{l}\text { Minor SiC- } \\
\text { polytypes }\end{array}$ \\
\hline BS90:10N & $2 \mathrm{H}_{\text {s.s. }}$ & $3 \mathrm{C}$ \\
BS90: $10 \mathrm{O}$ & $6 \mathrm{H}$ & $4 \mathrm{H}$ and 3C \\
BS100 & $6 \mathrm{H}$ and $4 \mathrm{H}$ & $15 \mathrm{R}$ and 3C
\end{tabular}

TABLE V Mechanical properties of $\beta$-SiC : $\mathrm{AlN}: \mathrm{Al}_{2} \mathrm{O}_{3}$ series

\begin{tabular}{lllll}
\hline Sample $^{\mathrm{a}}$ & $v$ & $E(\mathrm{GPa})$ & $H(\mathrm{GPa})$ & $K_{\mathrm{Ic}}(\mathrm{MPa}-\sqrt{\mathrm{m}})$ \\
\hline $\begin{array}{l}\beta \text {-SiC } \\
\quad \text { Standard })^{\mathrm{b}}\end{array}$ & 0.18 & 437 & $22.8 \pm 0.7$ & $2.7 \pm 0.2$ \\
BS50 & 0.19 & 368 & $20.3 \pm 0.8$ & $2.7 \pm 0.2$ \\
BS60 & 0.19 & 394 & $21.6 \pm 0.6$ & $2.9 \pm 0.2$ \\
BS70 & 0.18 & 406 & $20.7 \pm 0.6$ & $2.8 \pm 0.1$ \\
BS80 & 0.19 & 403 & $18.6 \pm 0.5$ & $5.3 \pm 0.3$ \\
BS90 & 0.18 & 428 & $14.8 \pm 1.0$ & $8.5 \pm 0.6$
\end{tabular}

${ }^{\mathrm{a}}$ All samples contain $0.5 \mathrm{wt} \% \mathrm{~B}$ added as a sintering aid. ${ }^{\mathrm{b}}$ Hot-pressed at $2050{ }^{\circ} \mathrm{C}$ with $1 \mathrm{wt} \% \mathrm{~B}$ and $1 \mathrm{wt} \% \mathrm{C}$ added as sintering aids.

with cracks appearing between $\mathrm{SiC}$ grains during crack propagation [16].

Scanning electron microscopy was performed on sample BS90 to try and determine a cause for this drastic increase in fracture toughness. Upon observation of Vicker's indentation produced radial/median cracks in the SEM, coupled with the XRD results, it was apparent that the $\beta$-SiC (3C) matrix had transformed into an elongated platelet containing $\alpha-\mathrm{SiC}(6 \mathrm{H})$ matrix. This microstructure resulted in a strong increase in crack deflection with definite bridging zones left behind the
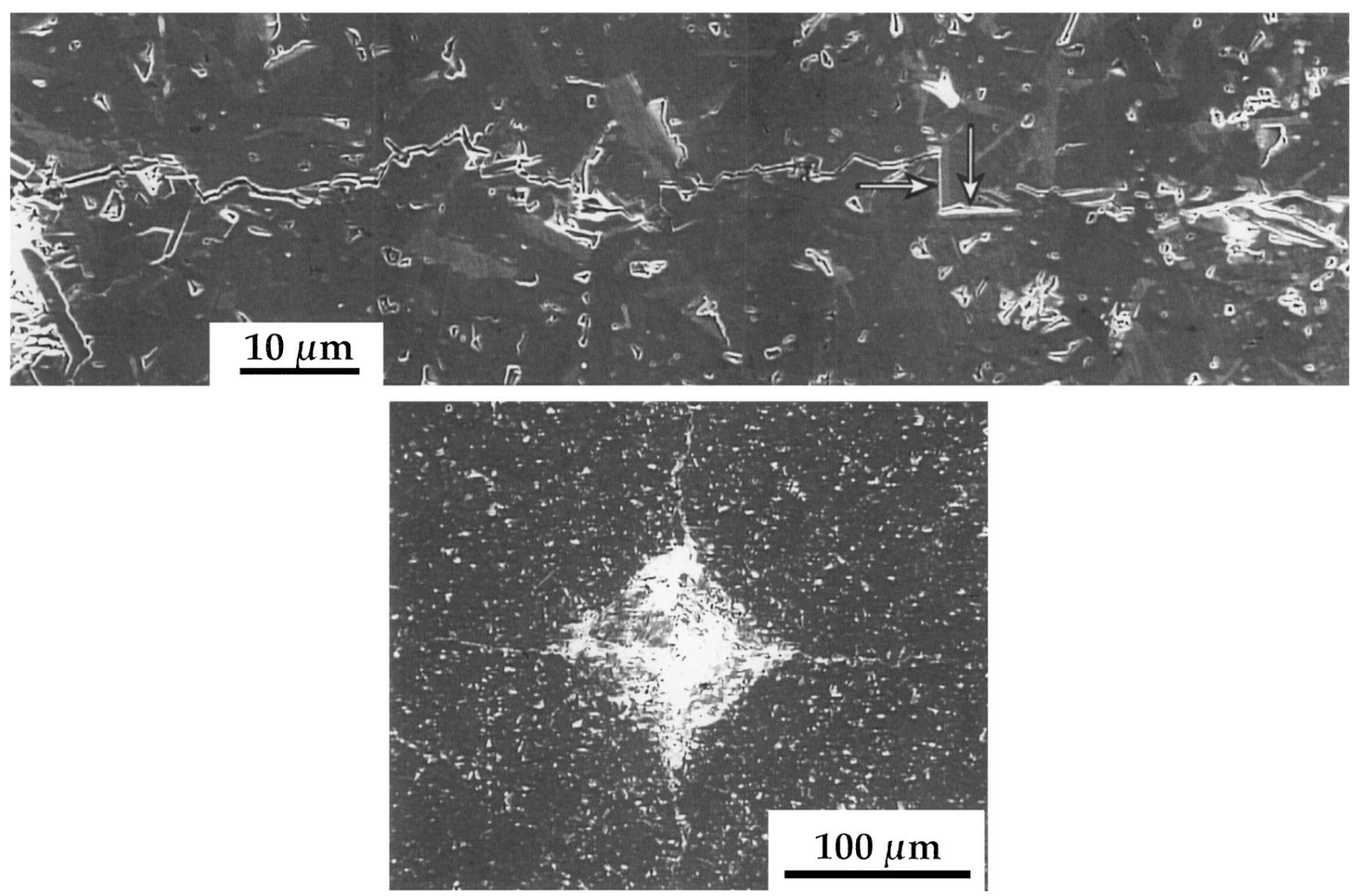

Figure 6 Radial/median cracks produced by a 20 kg Vicker's indent in composition BS90. 
advancing crack front. Previous researchers have observed limited to no improvement in the room temperature fracture toughness with the development of an elongated $\mathrm{SiC}$ matrix [17-19]. They typically reported that cracks still passed through a majority of the elongated $\mathrm{SiC}$ grains resulting in a mostly transgranular mode of brittle fracture. Fig. 6, from samples of the BS90 composition, clearly shows that the radial/median cracks preferred not to pass through the $6 \mathrm{H}-\mathrm{SiC}$ grains, but to follow a mode of intergranular fracture. The two arrows (inset in the figure) indicate where a radial/median crack has progressed straight into two different $6 \mathrm{H}-\mathrm{SiC}$ grains. Instead of penetrating the grains, the crack was deflected along the long axis of their interface before continuing on in the direction normal to the applied stress. This type of fracture mode is indicative of 'crack deflection' models [20,21] showing large increases in fracture toughness with high aspect ratio grains along with weak grain interfaces possibly due to residual tensile stresses at the grain boundaries.

It seems evident from the lack of crack deflection in previous $\mathrm{SiC}$ research containing elongated $\mathrm{SiC}$ grains [17-19], simply having high aspect ratio grains, either rod-like or platelet-like, was not enough to improve the fracture toughness of those particular compositions. Microstructural development must include control of the interfacial properties contiguous with design of the morphology of the microstructure to give rise to an improved toughening effect. This can occur through changes in the bonding strength and/or interfacial stress state between the matrix grains themselves or between the matrix and a dispersed second phase.

Methods for varying the interfacial stress state have typically included the addition of dispersed particulates or whisker reinforcements [22-25] and/or the addition of an intergranular phase [26,27]. Assuming that the intergranular phase forms a continuous layer throughout the matrix, and its thermal expansion coefficient is significantly different than that of the matrix, a high stress state can be created at the interface. Additionally, if the thermal expansion coefficient of the intergranular phase is greater than that of the matrix, during cooling from the processing temperature, a 'tensile' stress state will develop at the interface. This leads to a reduced bond strength and even microcracking at the interface if the thermal expansion coefficient of the intergranular phase is significantly high. Reduced bonding at the interface should result in improved fracture toughness for both ceramic monoliths and composites.

Crack deflection processes have also been shown to be enhanced by several other microstructural effects. The fracture path of an advancing crack has been shown to be altered by impurities at the grain boundaries and multi-grain junctions $[28,29]$, residual grain boundary porosity due to incomplete densification or poor processing [30], and residual tensile strains at the grain boundaries due to thermal expansion anisotropies in single phase polycrystalline materials [31]. An overview of toughening effects due to crack deflection, crack bridging and pullout including the effects of grain size and platelet formation, along with the effects of intergranular phases and stress induced microcracking has been written by Becher [32]
In the present study, no concerted effort was made to manipulate the interfacial stress state through the addition of an intergranular phase. Nevertheless, the improvements in fracture toughness are fundamental to the BS80 and BS90 compositions. From the above considerations of toughening enhancements, the increases observed in these materials are most likely produced by substantial residual tensile stresses at the grain boundaries possibly even giving rise to interfacial microcracking during crack propagation. The tensile stress state may have been affected both by the presence of an intergranular oxide phase and by stresses produced due to the thermal expansion and elastic modulus anisotropy associated with the large $\alpha$-SiC (6H) grains which have grown rapidly following the $\mathrm{SiC}$ phase transformation. Li and Bradt [33] have shown that the anisotropic behavior of $\mathrm{SiC}$ can lead to substantial thermoelastic stresses during cooling. This is most pronounced in the BS80 and BS90 compositions, and a strong case for microcracking is corroborated by their decrease in hardness concurrent with increasing fracture toughness.

In addition to the fracture toughness measurements obtained by the 'Direct Crack Measurements' technique [12], fracture toughness data was also obtained on three BS90 samples using the 'Controlled Surface Flaw' technique [15]. The fracture toughness values, summarized in Table VI, were uniform and had an average of $8.9 \pm 0.4 \mathrm{MPa}-\sqrt{\mathrm{m}}$. This was comparable to the direct crack measurement data obtained earlier, included in Table VI, where a fracture toughness value of $\sim 8.5 \pm 0.6 \mathrm{MPa}-\sqrt{\mathrm{m}}$ was obtained.

The high fracture toughness values obtained for the BS90 samples were emphasized by the large crack deflections as suggested by the observation of radial/median cracks produced by Vicker's indents (Fig. 6). The cracks are seen to deflect out of the plane normal to the applied stress. They follow a tortuous intergranular path through the microstructure to avoid the platelet shaped $\mathrm{SiC}$ grains.

Fracture toughness measurements were also performed on all samples hot pressed for 2 and $5 \mathrm{~h}$ at $2100^{\circ} \mathrm{C}$. The data is shown in Fig. 7 along with the data obtained at $2100{ }^{\circ} \mathrm{C}$ for a $1 \mathrm{~h}$ hold time. The change in

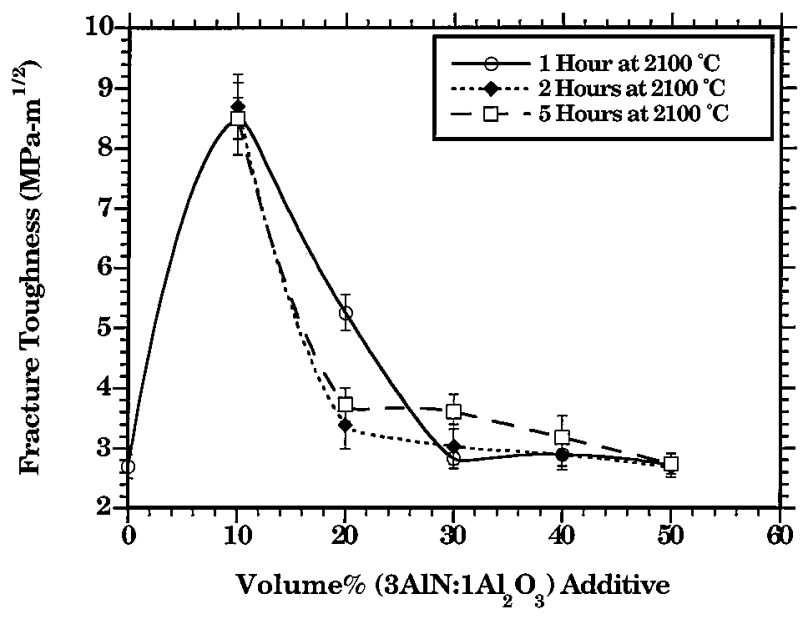

Figure 7 Fracture toughness vs. vol $\%$ additive for $\beta$-SiC: $\mathrm{AlN}: \mathrm{Al}_{2} \mathrm{O}_{3}$ series hot pressed at $2100^{\circ} \mathrm{C}$ for 1,2 , and $5 \mathrm{~h}$. 
TABLE VI Mechanical property data for BS90 composites hot-pressed for $1 \mathrm{~h}$ at $2100^{\circ} \mathrm{C}$

\begin{tabular}{llllll}
\hline Sample & $\begin{array}{l}\text { Width } \\
(\mathrm{mm})\end{array}$ & $\begin{array}{l}\text { Thickness } \\
(\mathrm{mm})\end{array}$ & $\begin{array}{l}E \\
(\mathrm{GPa})\end{array}$ & $\begin{array}{l}H \\
(\mathrm{GPa})\end{array}$ & $\begin{array}{l}K_{\mathrm{Ic}}(\mathrm{CSF})^{\mathrm{a}} \\
(\mathrm{MPa}-\sqrt{\mathrm{m}})\end{array}$ \\
\hline BS90-4 & 3.04 & 2.25 & 428 & 14.7 & $\begin{array}{l}K_{\text {Ic }}(\mathrm{DCM})^{\mathrm{b}} \\
(\mathrm{MPa}-\sqrt{\mathrm{m}})\end{array}$ \\
BS90-5 & 3.04 & 2.25 & 428 & 14.7 & -1 \\
BS90-9 & 3.04 & 2.25 & 428 & 14.7 & 9.2 \\
BS90 & - & - & 428 & 14.7 & - \\
\hline
\end{tabular}

${ }^{\mathrm{a} C S F}$ : Controlled surface flaw measurement. ${ }^{\mathrm{b}} \mathrm{DCM}$ : Direct radial/median crack measurement.

the fracture toughness values for compositions BS90, BS60, and BS50 for the longer hot pressing times was insignificant, while the fracture toughness of composition BS80 decreased and BS70 increased slightly. Again, XRD showed that the latter two compositions had not reached equilibrium after $1 \mathrm{~h}$ at $2100^{\circ} \mathrm{C}$, and therefore showed marked changes in polytypic phase content between 1 and $5 \mathrm{~h}$ at $2100^{\circ} \mathrm{C}$ (Figs 4 and 3, respectively).

\subsection{Flexural strength}

The results of the flexural strength measurements are summarized separately for each composition in Figs 8-10. The flexural strength values were quite

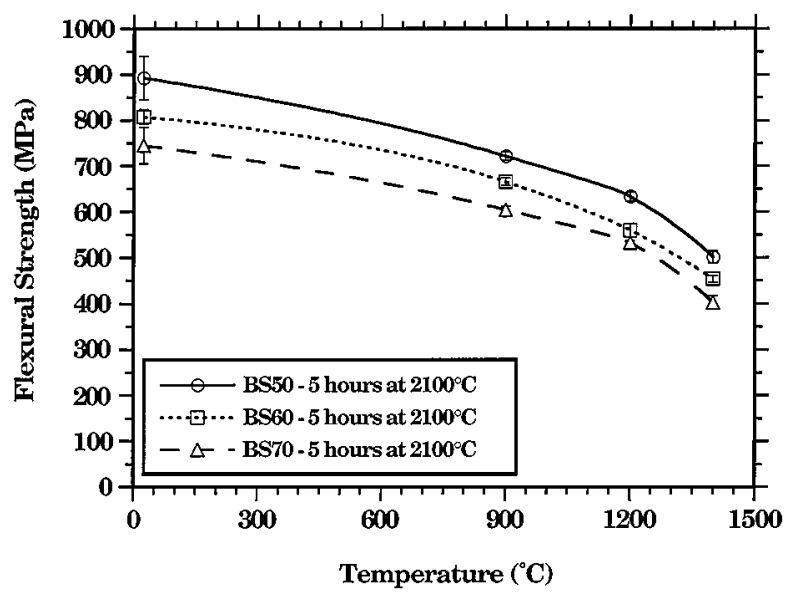

Figure 8 Plot of flexural strength vs. temperature for compositions BS50, BS60, and BS70 hot pressed for $5 \mathrm{~h}$ at $2100^{\circ} \mathrm{C}$.

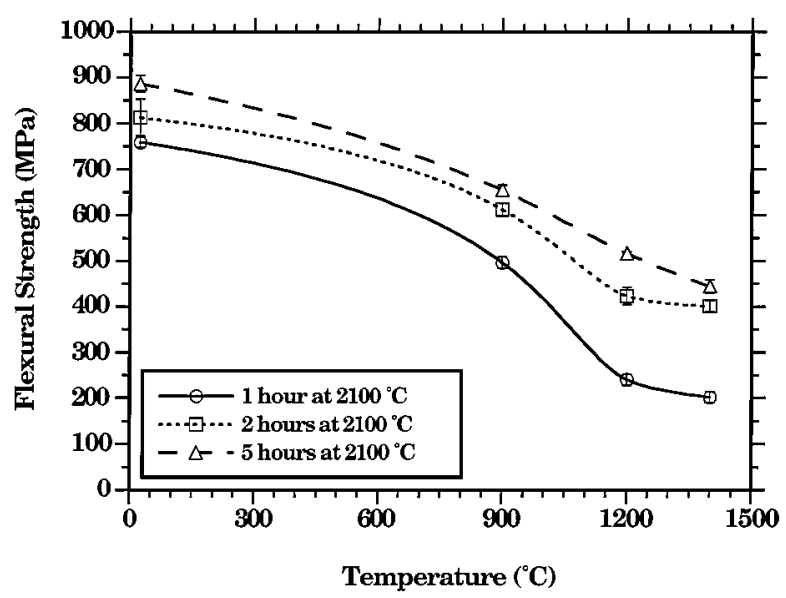

Figure 9 Plot of flexural strength vs. temperature for composition BS80 hot pressed for times of 1,2 , and $5 \mathrm{~h}$ at $2100^{\circ} \mathrm{C}$.

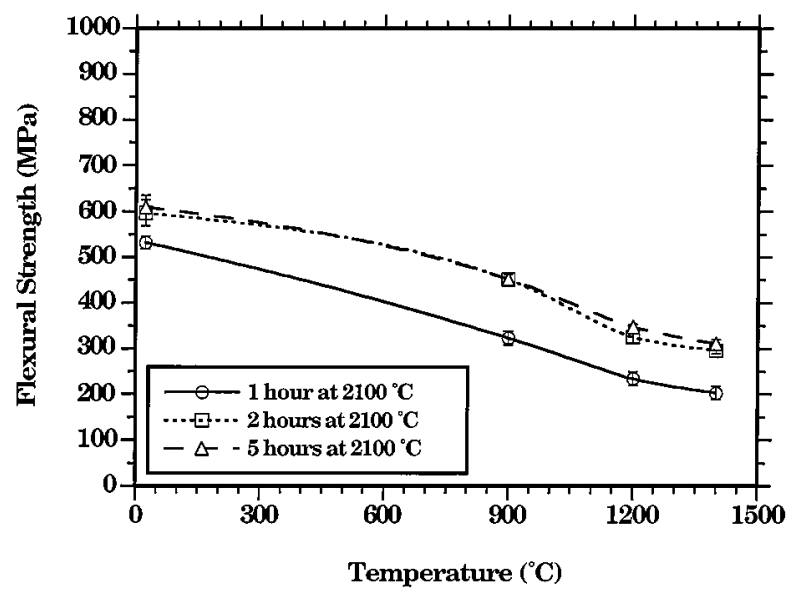

Figure 10 Plot of flexural strength vs. temperature for composition BS90 hot pressed for times of 1,2 , and $5 \mathrm{~h}$ at $2100^{\circ} \mathrm{C}$.

consistent, denoting a narrow flaw size distribution as indicated by the small error bars in the figures. The BS50 composition exhibited room temperature flexural strength values of 825-900 MPa. These values fell off gradually with increasing temperature to $1400{ }^{\circ} \mathrm{C}$ achieving strengths $\leq 500 \mathrm{MPa}$. Increasing the hot pressing hold time at $2100{ }^{\circ} \mathrm{C}$, a $5-10 \%$ gain in strength for all test temperatures. The BS60 composition is similar in strength to the BS50 composition except at room temperature. The room temperature strength after 1 and $2 \mathrm{~h}$ at $2100^{\circ} \mathrm{C}$ was $\sim 650 \mathrm{MPa}$ but increased to $>800 \mathrm{MPa}$ after $5 \mathrm{~h}$ at $2100{ }^{\circ} \mathrm{C}$. The room temperature strengths of composition BS70 were in the range of 750-825 $\mathrm{MPa}$. The strength level for both the BS60 and BS70 compositions decreased significantly with increasing temperature to a low of $\sim 400$ $\mathrm{MPa}$ at $1400{ }^{\circ} \mathrm{C}$. Since these three compositions were quite similar in their overall flexure behavior, their data has been summarized in Fig. 8 as a plot of flexural strength as a function of temperature for the longest hot pressing hold time of $5 \mathrm{~h}$ at $2100{ }^{\circ} \mathrm{C}$.

The BS80 composition, shown in Fig. 9, exhibited marked changes in flexural strength with both bend test temperature and hot pressing time. The room temperature strength increased from $>750 \mathrm{MPa}$ after $1 \mathrm{~h}$ at $2100{ }^{\circ} \mathrm{C}$ to $>875 \mathrm{MPa}$ after $5 \mathrm{~h}$. BS80 samples hot pressed only $1 \mathrm{~h}$ at $2100^{\circ} \mathrm{C}$ decreased in strength fairly rapidly above $900{ }^{\circ} \mathrm{C}$ to a low of $200 \mathrm{MPa}$, but those hot pressed for $5 \mathrm{~h}$ at $2100{ }^{\circ} \mathrm{C}$ decreased in strength gradually to a strength of $\sim 450 \mathrm{MPa}$.

The BS90 composition, shown in Fig. 10, had the lowest room temperature strength values of all five compositions, although was still high for a $\mathrm{SiC}$ composite, 
ranging from 525 to $600 \mathrm{MPa}$. The strength values were consistently $100 \mathrm{MPa}$ higher for longer hot pressing times of 2 and $5 \mathrm{~h}$, while decreasing gradually at higher bend test temperatures. The highest strengths were $\geq 300 \mathrm{MPa}$ at $1400{ }^{\circ} \mathrm{C}$.

\section{Conclusions}

XRD results showed that the polytypic content of a $\mathrm{SiC}$ matrix phase after hot pressing for $5 \mathrm{~h}$ at $2100^{\circ} \mathrm{C}$ is strongly affected by the amount of $\mathrm{AlN}$ and $\mathrm{Al}_{2} \mathrm{O}_{3}$ additions, with the two most predominate polytypes of $\alpha$-SiC being $2 \mathrm{H}$ and $6 \mathrm{H}$. Additions of only AlN resulted in a preferred transformation from $\beta$-SiC to the 2H-polytype of $\alpha$-SiC, while additions of only $\mathrm{Al}_{2} \mathrm{O}_{3}$ resulted in transformation to the $6 \mathrm{H}$-polytype of $\alpha-\mathrm{SiC}$.

Mechanical property data showed significant improvements in fracture toughness over hot pressed $\beta$-SiC (standard) materials. Fracture toughness values near $9 \mathrm{MPa}-\sqrt{\mathrm{m}}$ were achieved for samples of nominal composition 90 vol \% SiC : 10 vol \% (3AlN : $\left.1 \mathrm{Al}_{2} \mathrm{O}_{3}\right)$. Improvements in the fracture toughness appear to be the result of deflection of the cracks around elongated platelet-like $\mathrm{SiC}$ grains in an intergranular mode of fracture. Accompanying the improvements in fracture toughness were a notable decrease in hardness suggesting that microcracking may be responsible for the observed properties. For larger additions of $\mathrm{AlN}$ and $\mathrm{Al}_{2} \mathrm{O}_{3}$ (i.e. $>30$ vol $\% 3 \mathrm{AlN}: 1 \mathrm{Al}_{2} \mathrm{O}_{3}$ ), the fracture toughness values were $<3 \mathrm{MPa}-\sqrt{\mathrm{m}}$ and comparable to conventional $\mathrm{SiC}$ materials.

The entire series of $\mathrm{SiC}: \mathrm{AlN}: \mathrm{Al}_{2} \mathrm{O}_{3}$ composites exhibited high flexural strengths, with values ranging from $600 \mathrm{MPa}$ to nearly $900 \mathrm{MPa}$ at room temperature. The flexural strengths decreased gradually with increasing four-point bend test temperature for all of the compositions, typically to values that were $\sim 50 \%$ of the room temperature value at $1400{ }^{\circ} \mathrm{C}$.

\section{Acknowledgement}

This work was supported by the US Department of Energy, Office of Transportation Technologies, Advanced Materials Development Program under Contract No. DE-AC05-84OR2140.

\section{References}

1. S. SHINOZAKI and K. R. KINSMAN, in Proc. of the 14th Univ. Conf. on Ceramic Science of Processing of Crystalline Ceramics, edited by H. Palmer, R. F. Davis and T. M. Hare (North Carolina State Univ., Raleigh, NC, 1977) pp. 641-652.

2. Y. TAJIMA and W. D. KINGERY, J. Amer. Ceram. Soc. 65(2) (1982) C27-C29
3. S. S. SHINOZAKI, J. HANGAS, K. MAEDA and A. SoEtA, in "Ceramic Transactions," Vol. 2, Silicon Carbide '87, edited by J. D. Cawley and C. E. Semler (The American Ceramic Society, Westerville, OH, 1989) pp. 113-121.

4. R. M. Williams, B. N. JUterboCK, C. R. Peters and T. J. WHA LEN, J. Amer. Ceram. Soc. 67(4) (1984) C62-C64.

5. R. RUH and A. ZANGVIL, ibid. 65(5) (1982) 260-65.

6. W. RAFANIELLO, PhD dissertation, The University of Utah, June, 1984.

7. L. J. GAUCKLER, H. L. LUKAS and G. PETZOW, J.Amer. Ceram. Soc. 58(7) (1975) 346-47.

8. G. E. HILMAS, PhD dissertation, The University of Michigan, April, 1993.

9. J. RUSKA, L. J. GAUCKLER, J. LORENZ and H. U. REXER, J. Mat. Sci. 14 (1979) 2013-2017.

10. R. WYCKOFF, in "Crystal Structures," Vol. 1, 2nd ed. (Interscience, New York, 1963).

11. C. H. MACGillavRY and G. D. RieCK (eds.), "International Tables for X-ray Crystallography," Vol. 3 (Kynmoch Press, Birmingham, 1962).

12. G. R. ANSTiS, P. CHANTIKUL, B. R. LAWN and D. B. M A R S H A Ll, J. Amer. Ceram. Soc. 64(9) (1981) 533-538.

13. Proposed MIL-STD-1942A, "Flexure Strength of High Performance Ceramics at Ambient Temperatures,' US Army Materials Technology Laboratory, Watertown, MA, 1990.

14. Y. MURAKAMI (ed.), "Stress Intensity Factors Handbook," (Pergamon Press, New York, 1987).

15. P. CHANTIKUL, G. R. ANStis, B. R. LAWN and D. B. MARSHALl, J. Amer. Ceram. Soc. 64(9) (1981) 539-543.

16. H. - J. KLEEBE, J. Eur. Ceram. Soc. 10 (1992) 151-159.

17. G. ORANGE, H. TANAKA and G. FANTOZZI Ceram. Int. 13 (1987) 159-165.

18. S. G. SESHADRI, M. SRINIVASAN and K. Y. CHIA, in "Ceramic Transactions," Vol. 2, Silicon Carbide '87, edited by J. D. Cawley and C. E. Semler (The American Ceramic Society, Westerville, OH, 1989) pp. 215-226.

19. R. H. J. HANNINK, Y. BANDO, H. TANAKA and Y. INOMATA, J. Mater. Sci. 23 (1988) 2093-2101 (1988).

20. K. T. FABER and A. G. EVANS, Acta Met. 31(4) (1983) $565-576$.

21. K. T. FABER and A. G. EVANS ibid. 31(4) (1983) 577-584.

22. G. C. WEI and P. F. BECHER, J. Amer. Ceram. Soc. 67(8) (1984) 571-574.

23. C. H. MCMURTRY, W. D. G. BOECKER, S. G. SESHADRI, J. S. ZANGHI and J. E. GRANIER, Amer. Ceram Soc. Bull. 66(2) (1987) 325-329.

24. P. F. BECHER, C. H. HSUEH, P. ANGELINI and T. N. TIEGS, J. Amer. Ceram. Soc. 71(12) (1988) 1050-1061.

25. P. F. BECHER, ibid. 74(2) (1991) 255-269.

26. C. H. HSUEH, P. F. BECHER and P. ANGELINI, ibid. 71(11) (1988) 929-933.

27. Z. LI and R. C. BRADT, ibid. 72(1) (1989) 70-77.

28. F. F. LANGE, J. Mater. Sci. 10 (1975) 314-320.

29. Y. TAJIMA and W. D. KINGERY, ibid. 17(8) (1982) 2289-2297.

30. A. G. EVAns, J. Amer. Ceram. Soc. 65(10) (1982) 497-501.

31. Y. FU and A. G. EVANS, Acta Met. 30(8) (1982) 1619-1625.

32. P. F. BECHER, J. Amer. Ceram. Soc. 74(2) (1991) 255-269.

33. Z. LI and R. C. BRADT, in "Ceramic Transactions," Vol. 2, Silicon Carbide '87. edited by J. D. Cawley and C. E. Semler (The American Ceramic Society, Westerville, OH, 1989) pp. 313-339.

Received 1 October 1997

and accepted 27 April 1999 